\title{
THE RENAL HUMORAL PRESSOR MECHANISM IN MAN. IV. THE HYPERTENSINOGEN CONTENT OF THE PLASMA OF
NORMAL PATIENTS AND PATIENTS WITH
VARIOUS DISEASES ${ }^{1}$
}

By FLORENCE W. HAYNES AND LEWIS DEXTER

(From the Medical Clinic, Peter Bent Brigham Hospital, and the Department of Medicine, Harvard Medical School, Boston)

(Received for publication May 29, 1944)

In the plasma of dogs, hypertensinogen, the globulin substrate of renin, has been found to be increased after nephrectomy and decreased after the injection of renin (1). The liver has been claimed to be the chief source of hypertensinogen in dogs since removal or injury of the liver decreases or perhaps abolishes the regeneration of hypertensinogen $(2,3)$. From this experimental work it might be expected that the plasma of patients with kidney and liver disease would show abnormal hypertensinogen values. The present study deals with its determination in the plasma of patients with liver, kidney, cardiovascular, and various other diseases.

\section{METHODS}

Samples of 2 or $4 \mathrm{ml}$. of nonhemolyzed human plasma were incubated for 25 minutes, at $37^{\circ} \mathrm{C}$., at $\mathrm{pH} 7.3$, with an excess of human renin, as described in detail elsewhere (4). The hypertensin formed was assayed on cats by comparing the blood pressure rise obtained from the sample tested with that of a standard hypertensin solution. Each figure reported for hypertensinogen is the result of several tests, usually on 2 or more samples of plasma. Since the absolute values may vary somewhat with the sensitivity of the test animal, each pathological plasma was compared with one from a normal control, using the same solution of renin. Measurements of the non-protein nitrogen, total protein, albumin, globulin, and blood pressure were taken from the hospital records.

\section{RESULTS}

Diseases of the liver. At least 6 of the 10 patients listed in Table I had a low concentration of plasma hypertensinogen as compared with that of normal subjects. The decrease was most apparent in advanced cirrhosis with marked hepatic insufficiency. Values within about $\mathbf{4 0}$

1 This study was aided in part by a grant from the John and Mary R. Markle Foundation. per cent of the control must be considered within normal limits. Low hypertensinogen concentrations must be regarded critically since many defects in technic can lead to a low or incomplete formation of hypertensin, thus giving low values. It is probable, however, that the low hypertensinogen concentration in liver disease, as compared to that of normal controls, represents a defect in the formation of this protein. The decrease in hypertensinogen formed was not due to its destruction by hypertensinase in the plasma since the amount of plasma used was too small, the period of incubation too short for the hypertensinase to be effective, and the hypertensinase content of the plasma of cases 2, 8, and 9 was within normal limits.

Patients with various other disturbances. Of 12 patients who had elevated serum globulins (over 3.4 grams per cent), 8 have been mentioned under the section on liver disease (Table I). In the other 4 (cases $13,15,32,33$ ), the hypertensinogen was considered to be within normal limits (Table II). High serum globulin, therefore, does not necessarily imply an increase in the concentration of hypertensinogen. In $9 \mathrm{pa}$ tients with fever $\left(101^{\circ} \mathrm{F}\right.$. or above), the hypertensinogen concentration was normal (Tables I and II). With the exception of case 12, there was no evidence that the hypertensinogen concentration was altered by renal insufficiency with azotemia (cases 15, 16, 23, 32, 33, 36). Its concentration was also within normal limits in the following cases (Table II): Eight cases with chronic hypertension, 2 cases each of nephrosis, burns, Hodgkin's disease, and shock, 1 each of Addison's crisis, thyrotoxicosis, and multiple myeloma, and 5 cases with normal blood pressure under ether anesthesia. Two patients of the present series (cases 11, 12) and 1 of a previous 
TABLE I

The concentration of hypertensinogen in the plasma of patients with diseases of the liver

\begin{tabular}{|c|c|c|c|c|c|c|c|c|c|c|c|}
\hline \multirow{2}{*}{ Case } & \multirow{2}{*}{ Age } & \multirow{2}{*}{$\begin{array}{c}\text { Blood } \\
\text { pressure }\end{array}$} & \multirow{2}{*}{$\begin{array}{l}\text { Body } \\
\text { tem- } \\
\text { pera- } \\
\text { ture }\end{array}$} & \multirow{2}{*}{$\begin{array}{c}\text { Blood } \\
\text { urea } \\
\text { nitro- } \\
\text { gen }\end{array}$} & \multirow{2}{*}{$\begin{array}{c}\text { Non- } \\
\text { portein } \\
\text { nitro- } \\
\text { gen }\end{array}$} & \multirow{2}{*}{$\begin{array}{c}\text { Total } \\
\text { plasma } \\
\text { protein }\end{array}$} & \multirow{2}{*}{$\begin{array}{c}\text { Albumin } \\
\text { globulin } \\
\text { ratio }\end{array}$} & \multicolumn{3}{|c|}{ Hypertensinogen } & \multirow{2}{*}{ Diagnosis } \\
\hline & & & & & & & & Patient & Control & $\mid \begin{array}{c}\text { Differ- } \\
\text { ence from } \\
\text { control }\end{array}$ & \\
\hline & years & $m m . H_{g}$ & ${ }^{\circ} F$. & \multicolumn{2}{|c|}{ mem. per cent } & \multicolumn{2}{|c|}{ grams per cent } & \multicolumn{2}{|c|}{$\begin{array}{l}\text { cat units per } \\
\text { ml. plasma }\end{array}$} & per cent & \\
\hline $\begin{array}{l}1 \\
2 \\
3 \\
4 \\
5 \\
6 \\
7 \\
8 \\
9\end{array}$ & $\begin{array}{l}51 \\
67 \\
63 \\
57 \\
65 \\
65 \\
62 \\
52 \\
54\end{array}$ & $\begin{array}{l}110 / 70 \\
145 / 80 \\
165 / 84 \\
130 / 80 \\
110 / 70 \\
140 / 80 \\
115 / 70 \\
126 / 60 \\
100 / 66\end{array}$ & $\begin{array}{r}101.2 \\
100.5 \\
100.4 \\
99.3 \\
99.0 \\
99.0 \\
98.6 \\
100.0 \\
99.3\end{array}$ & $\begin{array}{r}6 \\
18 \\
8 \\
10\end{array}$ & $\begin{array}{l}32 \\
25 \\
25 \\
23 \\
34 \\
33\end{array}$ & $\begin{array}{l}8.1 \\
6.5 \\
6.3 \\
7.2 \\
5.4 \\
5.8 \\
6.7 \\
6.4 \\
6.7\end{array}$ & $\begin{array}{l}3.2 / 4.9 \\
3.1 / 3.4 \\
2.9 / 3.4 \\
3.5 / 3.7 \\
0.9 / 4.5 \\
2.1 / 3.7 \\
1.4 / 5.3 \\
2.4 / 4.0 \\
1.6 / 5.1\end{array}$ & $\begin{array}{l}5.0 \\
3.8 \\
2.5 \\
2.5 \\
1.9 \\
1.9 \\
1.7 \\
1.0 \\
1.2\end{array}$ & $\begin{array}{l}4.4 \\
3.7 \\
4.1 \\
4.5 \\
4.0 \\
4.5 \\
4.4 \\
3.7 \\
4.6\end{array}$ & $\begin{array}{l}+13 \\
+3 \\
-39 \\
-44 \\
-52 \\
-58 \\
-61 \\
-73 \\
-74\end{array}$ & $\begin{array}{l}\text { Carcinoma of esophagus } \\
\text { Cirrhosis } \\
\text { Cirrhosis } \\
\text { Alcoholic cirrhosis } \\
\text { Laennec's cirrhosis } \\
\text { Laennec's cirrhosis } \\
\text { Cirrhosis (advanced) } \\
\text { Cirrhosis (terminal) } \\
\text { Laennec's cirrhosis, pul- }\end{array}$ \\
\hline$* 10 a$ & 23 & $\begin{array}{l}125 / 68 \\
118 / 70\end{array}$ & $\begin{array}{l}101.0 \\
101.4\end{array}$ & & 25 & 6.0 & $2.1 / 3.9$ & $\begin{array}{l}1.1 \\
0.5\end{array}$ & $\begin{array}{l}3.9 \\
3.1\end{array}$ & $\begin{array}{l}-72 \\
-84\end{array}$ & $\begin{array}{l}\text { monary tuberculosis } \\
\text { Cirrhosis (terminal), } \\
\text { splenomegaly }\end{array}$ \\
\hline
\end{tabular}

* Sample "a" was taken a month before sample "b."

TABLE II

The concentration of hypertensinogen in the plasma of patients with various diseases

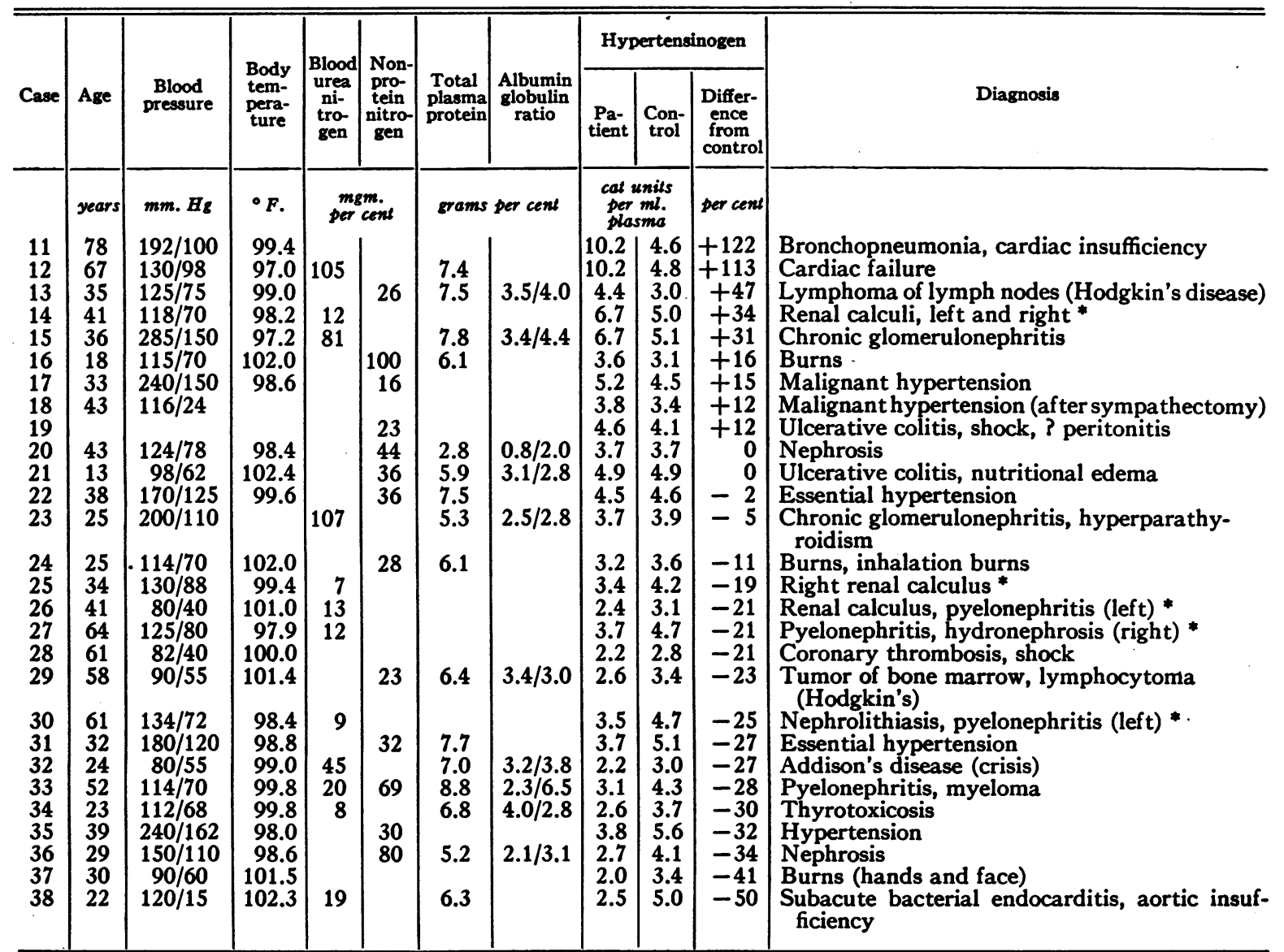

* Bloods were taken at operation under ether anesthesia. 
series showed elevated hypertensinogen values. These 3 had severe hypertensive or arteriosclerotic cardiovascular disease and were practically moribund when the determinations were made. The increase in concentration was not due to pressor substances in the fresh plasma since control tubes with plasma alone did not raise the blood pressure. An experiment in which urea was added to control plasma to make an 0.25 per cent solution indicated that urea itself did not increase the values for hypertensinogen.

\section{DISCUSSION}

The concentration of hypertensinogen in normal human beings was previously reported (5) as ranging from about 2 to 5 units per $\mathrm{ml}$., and Tables I and II show the ranges encountered. The average is considered to be approximately 4.1 cat units per $\mathrm{ml}$. This is in close agreement with the figure of $0.75(\mathrm{dog})$ unit (3.0 cat units) recently reported by others (6) who found the concentration varying from 0.6 to 1.32 (dog) units (2.4 to 5.3 cat units) in 12 normal individuals. Their method of assay was similar to ours except that they used a greater excess of human renin (400 cat units) and a shorter incubation period (7 minutes).

The results obtained on the variations in concentration of hypertensinogen in various diseases may be in part explained or anticipated from previous work in this and other laboratories. It might be expected that the concentration of hypertensinogen would be low in diseases which interfere with the synthesis of hypertensinogen and high in diseases which interfere with its destruction or conversion to hypertensin. A decrease in hypertensinogen in severe hepatic insufficiency was to be expected from animal experiments previously reported $(2,3)$. Our observations are further evidence that hypertensinogen, like albumin and some plasma globulins (7), is formed at least in part by the liver $(2,3)$. In diseases in which circulating renin is excessive, such as severe hypotension from hemorrhagic shock in dogs, the hypertensinogen concentration of plasma has been shown to decrease (8), presumably due to its being destroyed more rapidly than it can be synthesized. We have been unable to confirm the increase in hypertensinogen (renin substrate) in hypertension reported by one worker (9) who used the guinea pig ileum as an assay method.

The normal concentration of hypertensinogen in human hypertension may be explained by the lack of liver damage in clinical hypertension and by the absence of detectable amounts of renin in both experimental and human hypertension by current methods $(10,11)$ in all except those of explosive onset. The only cases in our series with definite increases in hypertensinogen were 2 elderly patients who were terminally ill with hypertensive cardiovascular disease (cases 11 and 12). Since the hypertensinogen concentration of dog plasma is increased after nephrectomy $(1,8)$, it might be expected that in very marked renal insufficiency the hypertensinogen concentration would be elevated. We do not have definite evidence that such is the case in human beings. It is possible, however, that this might be the explanation for the high hypertensinogen concentration in cases 11 and 12.

It is of interest to consider the chemical nature of hypertensinogen and to compare its concentration in different diseases with the electrophoretic serum patterns for these diseases reported in the literature. The hypertensinogen of beef serum has been found to be a pseudoglobulin, precipitated between 1.25 and 1.67 molar ammonium sulfate (12); by electrophoretic measurements, the hypertensinogen of hog serum was found (13) to be in the alpha-2 globulin fraction (1.85 to 2.10 molar ammonium sulfate) although traces of gamma globulin and albumin were present. Electrophoretic studies of sera from a small series of cases (14 to 16) indicate that the alpha globulins are increased in infectious diseases and especially in nephrosis; that the beta globulins are increased markedly in multiple myeloma and somewhat in nephrosis, and occasionally in liver disease; and that the gamma globulins are decreased in nephrosis, and increased in infections and liver disease, especially cirrhosis. The hypertensinogen cannot be correlated directly with any of these globulin fractions since it increased in a few terminal cases of uremia and cardiac failure and decreased in severe cirrhosis. Two cases of nephrosis had normal hypertensinogen concentrations (cases 20 and 36). Since each of the electrophoretic frac- 
tions of serum contains a large number of physiologically different proteins, the lack of correlation of hypertensinogen and electrophoretic results is not too surprising.

\section{SUMMARY}

Measurements have been made of the hypertensinogen concentration of the plasma of 10 patients with liver disease and 28 patients with various other diseases. The hypertensinogen concentration was found to be within normal limits in all except 2 hypertensive patients with terminal cardiac failure in whom it was increased and in 6 cases of severe cirrhosis in whom it was decreased. This gives further evidence that the liver is the principal site of formation of the globulin, hypertensinogen.

\section{BIBLIOGRAPHY}

1. Muñoz, J. M., Braun-Menendez, E., Fasciolo, J. C., and Leloir, L. F., The mechanism of renal hypertension. Am. J. M. Sc., 1940, 200, 608.

2. Page, I. H., McSwain, B., Knapp, G. M., and Andrus, W. D., The origin of renin-activator. Am. J. Physiol., 1941, 135, 214.

3. Leloir, L. F., Muñoz, J. M., Taquini, A. C., BraunMenendez, E., and Fasciolo, J. C., La formación del hipertensinogeno. Rev. argent. de cardiol., 1942, 9, 269.

4. Dexter, L., Haynes, F. W., and Bridges, W. C., The renal humoral pressor mechanism in man. I. Preparation and assay of human renin, human hypertensinogen, and hypertensin. J. Clin. Invest., $1945,24,62$.

5. Haynes, F. W., and Dexter, L., The hypertensinogen concentration of the plasma of patients with various diseases. Federation Proc., 1943, 2, 20.
6. Taquini, A. C., Braun-Menendez, E., Fasciolo, J. C., Leloir, L. F., and Muñoz, J. M., Medición del hipertensinogeno. Rev. Soc. argent. de biol., 1943, $19,500$.

7. Madden, S. C., and Whipple, G. H., Plasma proteins: Their source, production and utilization. Physiol. Rev., 1940, 20, 194.

8. Dexter, L., Frank, H. A., Haynes, F. W., and Altschule, M. D., Traumatic shock. VI. The effect of hemorrhagic shock on the concentration of renin and hypertensinogen in the plasma in unanesthetized dogs. J. Clin. Invest., 1943, 22, 847.

9. Page, I. H., Difference in the activating effect of normal and hypertensive plasma on intestinal segments treated with renin. Am. J. Physiol., 1940, 130, 29.

10. dell'Oro, R., and Braun-Menendez, E., Dosaje de renina en la sangre de perros hipertensos por isquemia renal. Rev. Soc. argent. de biol., 1942, $18,65$.

11. Dexter, L., and Haynes, F. W., The relation of renin to human hypertension with particular reference to eclampsia, preeclampsia, and acute glomerulonephritis. Proc. Soc. Exper. Biol. and Med., 1944, $55,288$.

12. Schales, O., Holden, M., and Schales, S. S., Reninsubstrate from beef serum. Arch. Biochem., 1943, 2, 67.

13. Plentl, A. A., Page, I. H., and Davis, W. W., The nature of renin activator. J. Biol. Chem., 1943, 147, 143.

14. Longsworth, L. G., Shedlovsky, T., and MacInnes, D. A., Electrophoretic patterns of normal and pathological human blood serum and plasma. J. Exper. Med., 1939, 70, 399.

15. Luetscher, J. A., Jr., Electrophoretic analysis of plasma and urinary proteins. J. Clin. Invest., 1940, 19, 313.

16. Gray, S. J., and Barron, E. S. G., The electrophoretic analyses of the serum proteins in diseases of the liver. J. Clin. Invest., 1943, 22, 191. 